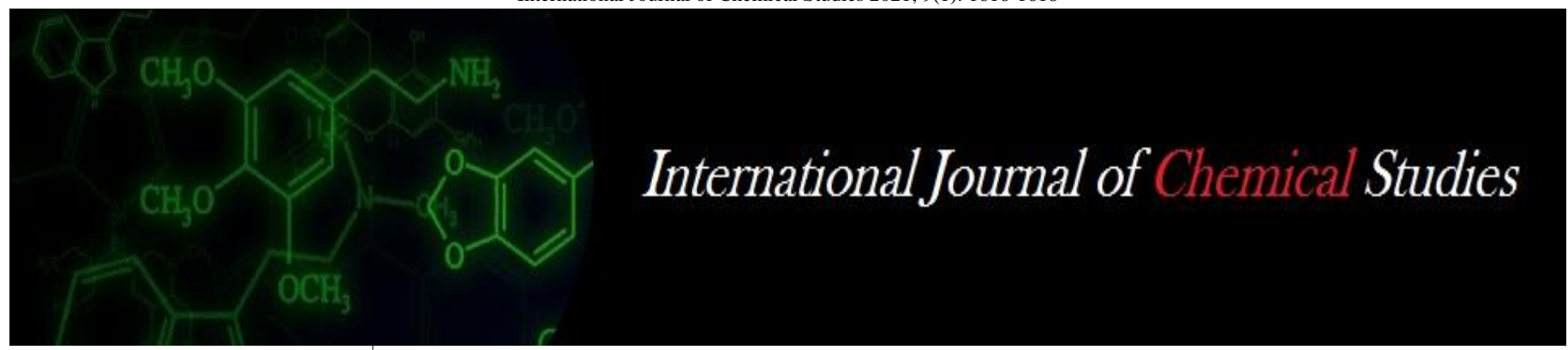

P-ISSN: 2349-8528

E-ISSN: 2321-4902

www.chemijournal.com

IJCS 2021; 9(1): 1616-1618

(C) 2021 IJCS

Received: 16-11-2020

Accepted: 18-12-2020

\section{AU Raut}

M.Sc. Student, Department of

Vegetable Science, Faculty of

Horticulture, Dr. Panjabrao

Deshmukh Krishi Vidyapeeth,

Akola, Maharashtra, India

\section{Dr. SM Ghawade}

Junior Breeder Cum

Horticulturist, Chilli and

Vegetable Research Unit,

Dr. Panjabrao Deshmukh Krishi

Vidyapeeth, Akola,

Maharashtra, India

\section{Dhaneshwari N Pachkhande}

M.Sc. Student, Department of

Genetics and Plant Breeding,

Faculty of Agriculture,

Dr. Panjabrao Deshmukh Krishi

Vidyapeeth, Akola,

Maharashtra, India

Bhagyashree S Sawant

M.Sc. Student, Department of

Plantation Spices, Medicinal and

Aromatic Crops, College of

Horticulture, Dr. Balasaheb

Sawant Konkan Krishi

Vidyapeeth, Dapoli,

Maharashtra, India

KA Dahatonde

M.Sc. Student, Department of Vegetable Science, Faculty of Horticulture, Vasantrao Naik Marathwada Krishi Vidyapeeth, Parbhani, Maharashtra, India

Corresponding Author:

\section{AU Raut}

M.Sc. Student, Department of

Vegetable Science, Faculty of

Horticulture, Dr. Panjabrao

Deshmukh Krishi Vidyapeeth,

Akola, Maharashtra, India

\section{Evaluation of yield and quality characteristics in dill (Anethum graveolens L.)}

\author{
AU Raut, Dr. SM Ghawade, Dhaneshwari N Pachkhande, Bhagyashree S \\ Sawant and KA Dahatonde
}

DOI: https://doi.org/10.22271/chemi.2021.v9.i1w.11459

\begin{abstract}
Dill (Anethum graveolens L.) is an annual herb in Umbelliferae family. An experiment conducted during rabi 2018-2019 at Chilli and Vegetable Research Unit, Dr. PDKV, Akola for evaluation of Yield and Quality Characteristics of Dill (Anethum graveolens L.). Among the sixteen genotypes viz., AKDIL-01, AKDIL-02, AKDIL-03, AKDIL-04, AKDIL-05, AKDIL-06, AKDIL-07, AKDIL-08, AKDIL-09, AKDIL-10, AKDIL-11, AKDIL-12, AKDIL-13, AKDIL-14, AKDIL-15, AKDIL-16 and one checkShiva. The experiment was laid out in a RBD with three replications. Among the genotypes plant height was ranged from $107.33 \mathrm{~cm}$ (AKDIL-07) to $153.33 \mathrm{~cm}$ (AKDIL-10) over check. Variation in yield and yield contributing characteristics were found among the sixteen dill genotypes. The genotype AKDIL-4 produced the maximum branches (6.40) followed by AKDIL-13 (6.33). A similar trend was also noticed in number of umbellets per umbel among the genotypes. The highest seed yield per plant was recorded in the genotype AKDIL-13 (14.7 g) while, it was the lowest in AKDIL-7 (3.67 g). For seed production potentiality, the genotype AKDIL-13 produced the highest amount of seed yield per plot $(362.00 \mathrm{~g})$ since it produced the maximum number of seeds per umbel (344.33). Seed yield per plot varied from $40.00 \mathrm{~g}$ to $362.00 \mathrm{~g}$.
\end{abstract}

Keywords: dill, genotypes, growth, yield, quality

\section{Introduction}

In recent years, the volume of use of Medicinal and Aromatic Plants (MAPs) increases with the formation of new usage areas and increasing the demand for natural products day by day. One of these plants is dill (Anethum graveolens L.), which is usually an annual herb in Umbelliferae (Apiaceae) family. Dill is a seed spice crop and an important aromatic herb, that is used for flavoring, tea, pickles, and confectionery. Dill leaves are rich in minerals and fibre. The seeds are mainly used for spice, culinary and medicinal purposes. It is also used as a vegetable and as aromatic herb (Sharma, 2004) ${ }^{[4]}$.

Dill is normally grown as a spice crop for seed purposes. Dill grows up to 40-60 cm as the leafy vegetable purpose and up to $145-155 \mathrm{~cm}$, when grown for the seed production. Dill has slender hollow stems and alternate, finely divided, softly delicate leaves of 10-20 cm length. The ultimate leaf divisions are 1-2 mm broad, slightly broader than similar leaves of fennel, which are thread-like, less than $1 \mathrm{~mm}$ thick, and straight to slightly curved with a longitudinally ridged surface. Usually, there were two types of dill seeds exist in cultivation. One is European dill and another is Indian dill. Dill is probably native to south-west Asia or south-east Europe and also has been cultivated since ancient times. India and Pakistani are the most producer countries of this plant. Moreover, USA, UK, Mexico, Germany, Hungary and Netherlands produce high amounts of dill. In addition to growing naturally, it also is grown in gardens in our country frequently.

In India, dill is grown with the name of Shepu or Shatapushpa or sowa (Anethum sowa) also known as Indian dill, in the states of Rajasthan, Gujarat, Maharashtra, Andhra Pradesh, and Madhya Pradesh for its seed. Dill is primarily a summer crop of the temperate region, but it has also adapted to grow in warmer areas. In the northern Indian plains, it is grown during the rabi season. In India, total area, production, and productivity of dill is 26.698 ha, 33,090 tonnes, and $1239.41 \mathrm{~kg} / \mathrm{ha}$ respectively (Anonymous, 2012) ${ }^{[1]}$ 


\section{Material and Methods}

The experiment entitled "Genetic variability and correlation studies in dill (Anethum graveolens L.)" was carried out at Chilli and Vegetable Research Unit, Dr. P.D.K.V., Akola during the rabi season of 2018-19. Total sixteen genotypes were included viz., AKDIL-01, AKDIL-02, AKDIL-03, AKDIL-04, AKDIL-05, AKDIL-06, AKDIL-07, AKDIL-08, AKDIL-09, AKDIL-10, AKDIL-11, AKDIL-12, AKDIL-13, AKDIL-14, AKDIL-15, AKDIL-16 and one check-Shiva. All the cultural practices were followed to raise the normal crop. The study was undertaken on sixteen genotypes including one check-Shiva of dill using Randomized Block Design with three replications. The observations were recorded on five randomly selected plants of each genotype in each replication for fourteen characters and average values were used for statistical analysis. The data was recorded on quantitative as well as qualitative parameters like Plant height, number of branches, numbers of umbels per plant, number of umbellets per umbel, seed yield per plant, number of seeds per umbel, number of seeds per umbellets, test weight, oil content, days to $1^{\text {st }}$ flowering, days to $50 \%$ flowering, days to maturity, germination percentage, seed yield per plot.

\section{Results and Discussion}

The analysis of variance was calculated for all fourteen characters studied and their mean squares values are presented in table 1. The mean square due to genotypes was highly significant for all characters, while the mean square due to replication were highly non-significant for all characters. The mean performance of all genotypes presented in table 2 . Among the sixteen genotypes AKDIL-10 produced maximum plant height $(153.33 \mathrm{~cm})$ whereas, AKDIL-7 exhibited minimum plant height $(107.33 \mathrm{~cm})$ followed by AKDIL-14 and AKDIL-12. The number of branches was in between 3.67 to 6.40. AKDIL-4 had produced maximum branches (6.40) followed by AKDIL-13, AKDIL-05, AKDIL-06, AKDIL-02 and AKDIL-15 while, AKDIL-7 exhibited minimum branches (3.67. Similar findings were reported by Jyothi et al. (2017) ${ }^{[3]}$ in coriander, under Rajendranagar conditions.

AKDIL-5 had fabricated the maximum (6.53) umbels of dill it was found at par with AKDIL-10, AKDIL-13, AKDIL-03,
AKDIL-01, AKDIL-12, AKDIL-04, AKDIL-08 and AKDIL15 while, genotype AKDIL-7 was produced minimum umbels (5.00). Among all AKDIL-4 was able to produce maximum (19.67) umbellets and found at par with AKDIL-16, AKDIL13 and AKDIL-14 while, AKDIL-7 had exhibited minimum (16.83) umbellets per umbel. AKDIL-13 (14.07 g) was able to produce maximum yield per plant and it was followed by AKDIL-4 while, AKDIL-7 fabricated minimum (6.03 g) seed yield per plant. Similar findings were reported by Singh et al. (2008) [5] in ajwain under Ajmer conditions, AKDIL-13 produced a maximum (344.33) number of seed per umbel and found at par with AKDIL-5 and AKDIL-4 whereas, AKDIL-7 had produced a minimum (96.00) seeds per umbel. Among all AKDIL-4 produced a maximum (15.00) seeds per umbellets and found at par with AKDIL-5, AKDIL-08, AKDIL-11, AKDIL-13, AKDIL-15, AKDIL-01, AKDIL-12, AKDIL-02, AKDIL-17, AKDIL-14, AKDIL-03, AKDIL-10 and AKDIL16 while, AKDIL-7 exhibited a minimum (9.00) number of seeds per umbellets. Similar findings were reported by Dhakad et al. (2017) ${ }^{[2]}$ in coriander under Jabalpur conditions.

AKDIL-16 (3.46 g) was maximum test weight and found at par with AKDIL-12 while, AKDIL-7 (2.29 g) was reported a minimum test weight. Among all AKDIL-6 was found with maximum $(9.67 \%)$ oil content which was found at par with AKDIL-10. while, AKDIL-12 exhibited a minimum (6.60\%) oil content. AKDIL-15 was the earliest one (62.67) in flowering which is desirable while, AKDIL-7 was a late genotype (74.67). Earliest days to $50 \%$ flowering observed for AKDIL-4 (71.00) while, AKDIL-7 was late (82.33) for 50\% flowering. AKDIL-4 was earliest maturity (143.00) while, the genotype AKDIL-7 (156.00) was late for maturity. AKDIL14 and AKDIL-15 expressed a maximum (96.33\%) germination percentage where, genotype AKDIL-3 was reported with minimum $(71.67 \%)$ gemination percentage. AKDIL-13 produced a maximum $(362.00 \mathrm{~g})$ seed yield followed by AKDIL-4 and AKDIL-5 while, genotype AKDIL-7 exhibited minimum yield per plot (40.00 g). Similar results were reported by Solanki et al. (2014) ${ }^{[6]}$ in dill under Udaipur conditions.

Table 1: Analysis of variance for different characters of dill

\begin{tabular}{|c|c|c|c|}
\hline Characters & Replication (2) & Treatment (16) & Error (32) \\
\hline Plant height & 5.353 & $386.061^{* *}$ & 52.999 \\
\hline Number of branches & 0.217 & $1.181^{* *}$ & 0.116 \\
\hline Numbers of umbels per plant & 0.551 & $0.491^{* *}$ & 0.186 \\
\hline Number of umbellets per umbel & 0.236 & $1.421^{* *}$ & 0.536 \\
\hline Seed yield per plant & 0.01 & $15.79^{* *}$ & 0.252 \\
\hline Number of seeds per umbel & 825.961 & $10,739.30^{* *}$ & 381.315 \\
\hline Number of seeds per umbellets & 6.725 & $6.713^{* *}$ & 2.434 \\
\hline Test weight & 0 & $0.355^{*}$ & 0.001 \\
\hline Oil content & 0.018 & $1.96^{*}$ & 0.289 \\
\hline Days to 1st flowering & 30.353 & $34.478^{* *}$ & 13.103 \\
\hline Days to 50\% flowering & 23.529 & $19.865^{* *}$ & 7.509 \\
\hline Days to maturity & 0.235 & $39.664^{* *}$ & 14.881 \\
\hline Germination percentage & 56.137 & $229.505^{*}$ & 19.012 \\
\hline Seed yield per plot & 287.137 & $19,840.07^{* *}$ & 399.158 \\
\hline
\end{tabular} ,** Significant at 5\% and 1\% level, respectively
( )value in parentheses indicates degree of freedom


Table 2: Mean performances of seventeen dill genotypes

\begin{tabular}{|c|c|c|c|c|c|c|c|c|c|c|c|c|c|c|}
\hline Genotypes & $\begin{array}{c}\text { Plant } \\
\text { height } \\
(\mathrm{cm})\end{array}$ & $\begin{array}{c}\text { Number } \\
\text { of } \\
\text { branches }\end{array}$ & $\begin{array}{c}\text { Number } \\
\text { Umbels } \\
\text { per plant }\end{array}$ & $\begin{array}{c}\text { Number of } \\
\text { umbellets } \\
\text { per umbel }\end{array}$ & $\begin{array}{c}\text { Seed yield } \\
\text { per plant } \\
(\mathrm{g})\end{array}$ & $\begin{array}{c}\text { Number } \\
\text { of seed } \\
\text { per umbel }\end{array}$ & $\begin{array}{c}\text { Number of } \\
\text { seed per } \\
\text { umbellet }\end{array}$ & $\begin{array}{c}\text { Test } \\
\text { weight }\end{array}$ & $\begin{array}{c}\text { Oil } \\
\text { content } \\
(\%)\end{array}$ & $\begin{array}{c}\text { Days to } \\
1^{\text {st }} \\
\text { flowering }\end{array}$ & \begin{tabular}{|c|} 
Days to \\
$\mathbf{5 0 \%}$ \\
flowering
\end{tabular} & $\begin{array}{c}\text { Days to } \\
\text { maturity }\end{array}$ & $\begin{array}{c}\text { Germin } \\
\text { ation } \\
\text { test }(\%)\end{array}$ & $\begin{array}{c}\text { Seed } \\
\text { yield per } \\
\text { plot } \\
\text { (g) }\end{array}$ \\
\hline & 1 & 2 & 3 & 4 & 5 & 6 & 7 & 8 & 9 & 10 & 11 & 12 & 13 & 14 \\
\hline AKDIL-01 & 136.67 & 5.20 & 6.10 & 18.33 & 6.73 & 297.33 & 13.67 & 3.37 & 7.67 & 68.33 & 74.67 & 149.00 & 79.33 & 104.33 \\
\hline AKDIL-02 & 144.00 & 5.87 & 5.47 & 17.80 & 10.47 & 280.67 & 13.33 & 3.39 & 8.40 & 68.00 & 77.00 & 146.33 & 92.00 & 230.33 \\
\hline AKDIL-03 & 136.00 & 5.40 & 6.13 & 17.83 & 8.90 & 263.00 & 12.67 & 2.98 & 7.60 & 70.67 & 77.67 & 150.00 & 71.67 & 146.00 \\
\hline AKDIL-04 & 136.00 & 6.40 & 6.00 & 19.67 & 12.20 & 289.67 & 15.00 & 2.73 & 7.60 & 64.33 & 71.00 & 143.00 & 75.33 & 319.67 \\
\hline AKDIL-05 & 133.33 & 6.20 & 6.53 & 17.80 & 10.80 & 314.67 & 14.67 & 2.60 & 7.40 & 66.33 & 73.67 & 145.00 & 83.67 & 217.33 \\
\hline AKDIL-06 & 151.67 & 6.00 & 5.17 & 18.30 & 10.53 & 179.33 & 11.33 & 2.73 & 9.67 & 65.67 & 72.67 & 148.33 & 92.33 & 207.67 \\
\hline AKDIL-07 & 107.33 & 3.67 & 5.00 & 16.83 & 6.03 & 96.00 & 9.00 & 2.29 & 8.40 & 74.67 & 82.33 & 156.00 & 73.67 & 40.00 \\
\hline AKDIL-08 & 138.00 & 5.20 & 6.00 & 18.17 & 6.80 & 252.33 & 14.33 & 3.35 & 7.80 & 66.00 & 74.67 & 152.33 & 85.33 & 100.33 \\
\hline AKDIL-09 & 146.00 & 5.13 & 5.73 & 18.27 & 6.53 & 208.00 & 11.67 & 2.86 & 8.60 & 69.00 & 76.33 & 147.33 & 74.00 & 99.33 \\
\hline AKDIL-10 & 153.33 & 5.40 & 6.33 & 17.77 & 7.77 & 181.33 & 12.67 & 3.11 & 9.33 & 66.33 & 73.00 & 146.00 & 95.33 & 123.33 \\
\hline AKDIL-11 & 146.00 & 5.47 & 5.53 & 17.90 & 10.47 & 224.00 & 14.33 & 3.35 & 8.60 & 66.67 & 75.33 & 150.33 & 92.33 & 160.00 \\
\hline AKDIL-12 & 126.00 & 5.60 & 6.07 & 17.30 & 9.77 & 250.33 & 13.67 & 3.44 & 6.60 & 73.00 & 75.67 & 153.00 & 85.00 & 143.00 \\
\hline AKDIL-13 & 139.33 & 6.33 & 6.27 & 19.00 & 14.07 & 344.33 & 14.33 & 3.36 & 7.93 & 70.67 & 75.67 & 143.33 & 94.67 & 362.00 \\
\hline AKDIL-14 & 120.67 & 5.80 & 5.67 & 18.70 & 10.47 & 297.00 & 13.00 & 3.07 & 6.63 & 66.00 & 74.67 & 144.67 & 96.33 & 162.33 \\
\hline AKDIL-15 & 144.67 & 5.87 & 5.93 & 18.33 & 9.83 & 274.67 & 14.33 & 3.28 & 8.47 & 62.67 & 73.33 & 147.33 & 96.33 & 169.33 \\
\hline AKDIL-16 & 140.67 & 5.47 & 5.77 & 18.10 & 7.87 & 227.33 & 12.33 & 3.46 & 8.07 & 63.33 & 77.67 & 148.33 & 90.00 & 151.67 \\
\hline AKDIL-17 & 140.33 & 5.33 & 5.73 & 19.23 & 6.23 & 238.67 & 13.33 & 3.23 & 8.13 & 63.33 & 73.67 & 143.67 & 93.33 & 104.00 \\
\hline Mean & 137.65 & 5.55 & 5.85 & 18.20 & 9.15 & 248.16 & 13.16 & 3.09 & 8.05 & 67.35 & 75.24 & 147.88 & 86.51 & 167.10 \\
\hline RANGE & $\begin{array}{c}107.33 \\
153.33 \\
\end{array}$ & $3.67-6.40$ & $5.00-6.53$ & $16.83-19.67$ & $\begin{array}{l}6.03- \\
14.07\end{array}$ & $\begin{array}{l}96.00- \\
344.33\end{array}$ & $9.00-14.67$ & $\begin{array}{c}2.29- \\
3.46\end{array}$ & $\begin{array}{c}6.60- \\
9.67\end{array}$ & $\begin{array}{l}62.67- \\
74.67\end{array}$ & $\begin{array}{l}71.00- \\
82.33\end{array}$ & $\begin{array}{c}143.00- \\
156.00\end{array}$ & \begin{tabular}{|c|}
$96.33-$ \\
71.67
\end{tabular} & $\begin{array}{l}40.00- \\
362.00\end{array}$ \\
\hline SE(d) & 5.94 & 0.28 & 0.35 & 0.60 & 0.41 & 15.94 & 1.27 & 0.02 & 0.44 & 2.96 & 2.24 & 3.15 & 3.56 & 16.31 \\
\hline $\mathrm{SE}(\mathrm{m})$ & 4.20 & 0.20 & 0.25 & 0.42 & 0.29 & 11.27 & 0.90 & 0.02 & 0.31 & 2.09 & 1.58 & 2.28 & 2.52 & 11.53 \\
\hline $\mathrm{CV}$ & 5.29 & 6.13 & 7.37 & 4.02 & 5.49 & 7.87 & 11.86 & 0.92 & 6.67 & 5.37 & 3.64 & 2.61 & 5.04 & 11.96 \\
\hline CD@ @ $5 \%$ & 12.16 & 0.57 & 0.72 & 1.22 & 0.84 & 32.62 & 2.61 & 0.05 & 0.90 & 6.05 & 4.58 & 6.45 & 7.28 & 33.38 \\
\hline
\end{tabular}

$*$,** significant at $5 \%$ and $1 \%$ level, respectively

\section{Conclusion}

Among the genotypes, the genotypes AKDIL-13 AKDIL-04 and AKDIL-05 showed better performance especially in respect of seed yield per plot. AKDIL-6 performed well for oil content and AKDIL-7 showed high vegetative growth. Therefore, these genotypes can be taken under consideration for commercial cultivation.

\section{References}

1. Anonymous. Data on seed spices in India. National Horticulture Board, New Delhi 2012.

2. Dhakad RS, Sengupta SK, Lal N, Shiurkar G. Genetic diversity and heritability analysis in coriander. The Pharma Innovation Journal 2017;6(8):40-46.

3. Jyothi K, Mishra RP, Sujatha M, Joshi V. Genetic variability, heritability and genetic advance for yield and its component in indigenous collection of coriander (Coriandrum sativum L.) germplasm. International Journal of Pure \& Applied Bioscience 2017;5(3):301305.

4. Sharma A. Agro-techniques of Medicinal Plants. Daya Publishing House, New Delhi 2004.

5. Singh D, Choudhary SP. Evaluation of ajwain (Trachyspermum ammi L.) genotypes suitable for semiarid regions. Journal of Spices and Aromatic Crops 2008;17:167-171.

6. Solanki SK, Dodiya NS. Assessment of genetic variability, correlation for yield and its components characters in dill (Anethum graveolens L.). International J. Plant Sci 2014;9(1):234-236. 